\title{
AS FREGUESIAS - HISTÓRIA E ACTUALIDADE ${ }^{1}$
}

\author{
Carlos Mendes Pauleta ${ }^{2}$
}

O facto de as freguesias, na sua dimensão político-administrativa, serem uma realidade sem paralelo noutros países, associado aos escassos meios e reduzidas competências de que dispõem, explicará o pouco interesse que tem despertado o seu estudo que praticamente se tem resumido a alguns artigos ou a curtas referências inseridas em obras de maior vulto.

No entanto, numa altura em que as freguesias adquirem um novo fôlego, em boa parte por mérito próprio, é natural que aquelas autarquias despertem o interesse de alguns estudiosos. O trabalho de José António Santos, "As Freguesias História e actualidade", publicado em 1995, parece reflectir esta viragem na vida das freguesias. Naquela obra, o autor analisa as freguesias numa perspectiva histórica, desde a sua origem, sem esquecer o presente e espreitando o futuro.

O livro está organizado em oito capítulos. O primeiro esclarece a origem e a base etimológica de palavras que "o vocabulário eclesiástico cedo incorporou" e "o tempo se encarregaria de universalizar e de lhes atribuir significação e uso um tanto diferenciados dos adquiridos originalmente" tais como: "igreja", "diocese", "paróquia", "freguesia" e "colação".

Os capítulos seguintes são dedicados ao estudo da freguesia desde o período romano até ao Estado Novo. O último, que representa cerca de um quarto da obra, é constituído pela análise da actualidade, fazendo um curto exercício prospectivo no final.

Socorrendo-se do Padre Miguel de Oliveira, o autor detecta o "início da formação das primitivas freguesias" ainda no período romano, coincidindo com a cristianização da Península, no final do século III e início do século IV. Porém, importa não ignorar que as paróquias daquela época pouco tinham a ver com as actuais. O território não se afirmava como um elemento importante, a paróquia era essencialmente "uma comunidade de fieis adstritos a determinada igreja e ainda não propriamente uma circunscrição geográfica explicitada".

\footnotetext{
1 SANTOS, José António (1995) - As Freguesias - História e actualidade, Celta Editores, Oeiras.

2 Colaborador do C.E.G. no projecto de investigação "Poder Local e Políticas Sociais" (Pj. SSPS/C/PCL/2608/96, JNICT-MSSS).
} 
Com a ocupação árabe "as estruturas episcopal e paroquial foram objecto dum processo de acelerada desorganização". No entanto, com a reconquista e a subsequente formação de Portugal (que constitui o objecto do $3 .^{\circ}$ capítulo) J. A. Santos assinala o incremento das paróquias que ficou a dever-se "à passagem de oratórios e basílicas a igrejas baptismais", revelando, ainda, que "a construção de igrejas e o erigir de freguesias descendem com frequência da expressa vontade das comunidades já municipalmente organizadas".

Já num período em que o território se encontra consolidado o autor detecta a existência de um número muito maior de freguesias no norte do país, facto que se mantém na actualidade. A explicação defendida para este fenómeno reside em factores de natureza geográfica, relacionados com a fertilidade agrícola, o tipo de povoamento disperso, a maior densidade demográfica e factores histórico-eclesiásticos que determinaram uma mais estruturada e temporã organização das populações.

J. A. Santos entende que em paralelo com a estruturação das organizações municipais as freguesias afirmam-se crescentemente como "organizadoras do universo comunitário local" e que, em seu redor, estabelecem-se laços "religiosos, culturais, educativos e assistenciais das populações", revelando a existência de velhas preocupações sociais que foram transportadas até ao presente e continuam a constituir parte significativa das competências e da actividade das actuais freguesias.

Pela leitura de J. A. Santos torna-se evidente que o liberalismo constituiu, para as freguesias, um período de transição, em que a paróquia passou de circunscrição eclesiástica à entidade administrativa dos nossos dias. Verdadeiramente, a actual freguesia, embora herdeira de muitas das características da paróquia que a antecedeu, foi um fruto da revolução liberal.

Com o liberalismo, iniciou-se uma sucessão de acontecimentos que começaram com a criação, em 1830, das juntas de paróquia, com atribuições na área do culto religioso mas com direito a promoverem e administrarem todos os negócios que fossem de interesse puramente local. Cumpria-lhes conservar e reparar a igreja paroquial, receber e administrar os rendimentos e esmolas da igreja, mas também, cuidar da conservação de fontes, poços, pontes, caminhos, baldios, e, por outro lado, cuidar da saúde pública, e vigiar as escolas do ensino primário.

Só em 1835, as paróquias passam a integrar a divisão administrativa do país e são atribuídas funções administrativas às juntas paroquiais. Mas seria "sol de pouca dura”, já que, em 1840, são excluídas do edifício administrativo, mantendose afastadas dele por 27 anos. Com efeito, somente em 1867, na sequência da reforma administrativa de Martens Ferrão, foi criada a paróquia civil com o objectivo de gerir os interesses colectivos das populações, mas mantendo, também, funções relacionadas com a administração dos bens da igreja.

Esta reforma foi consagrada no código administrativo de 1878. A partir daquela data, a freguesia passou a ser considerada uma autarquia local e iniciou 
um percurso de consolidação como entidade administrativa, mantendo, no entanto, ligação à igreja, da qual só viria a afastar-se na vigência da Primeira República.

$\mathrm{O}$ novo regime reconheceu aos corpos administrativos independência perante o poder central, dotou as autarquias de órgãos executivos próprios, adoptou princípios descentralizadores e autonómicos remetendo a capacidade de anular ou modificar as suas deliberações para os tribunais, alargou o rol de competências e permitiu o recurso às contribuições directas e a empréstimos que passaram a fazer parte das suas fontes de financiamento.

É neste período que a paróquia civil adquire a denominação de freguesia, e o seu corpo administrativo a designação de junta de freguesia.

Com a tomada do poder pelos militares, em 1926, e a instauração do Estado Novo, dá-se início a um novo período, só interrompido 48 anos mais tarde, caracterizaado pelo retrocesso em vários aspectos da vida das freguesias, salientando-se a perda de independência e autonomia.

As juntas de freguesia continuavam a ser eleitas, embora por um colégio eleitoral restringido aos chefes de família, mas podiam ser destituídas pelos presidentes de Câmara, ou pelos governadores civis, no caso de Lisboa e Porto, que exerciam a tutela de natureza inspectiva e correctiva sobre as freguesias, isto apesar de terem menor legitimidade democrática uma vez que não eram eleitos.

Na República Democrática, designação que o autor utiliza para caracterizar o actual regime, as freguesias voltaram a estar em pleno na organização administrativa do Estado português, readquiriram autonomia e beneficiam da descentralização da administração pública.

A Constituição da República e as leis ordinárias reconhecem à freguesia um conjunto de preceitos basilares que J. A. Santos sintetiza em seis pontos a saber:

- Órgãos deliberativos e executivos cujos titulares são eleitos pelos cidadãos;

- Finanças e património;

- Atribuições e competências e, neste âmbito, a prática de actos definitivos e executórios;

- Poderes regulamentares;

- Quadros de pessoal e sua gestão;

- Tutela administrativa de mera aferência da legalidade.

No último capítulo o autor identifica, também, os órgãos das freguesias e a forma como se constituem; o facto de as atribuições e competências que refere não se distinguirem de outros níveis de administração autárquica; os escassos meios financeiros, que obrigam, este nível de administração a actuar em articulação com os municípios; e as condições para a criação de novas freguesias.

J. A. Santos apercebeu-se de que "as diversidades geográficas, sociais, económicas e demográficas dos núcleos populacionais", condicionam a funcionalidade das freguesias. Em consequência, podem distribuir-se por quatro padrões diferentes: "as freguesias rurais; as freguesias das sedes dos municípios; as freguesias sediadas nas áreas urbanas em expansão; e as freguesias das grandes cidades." 
Para todos os tipos de freguesia o autor apresenta uma visão pessimista, baseada na insuficiência de meios e de instrumentos de intervenção de que elas dispõem.

Por fim, num olhar sobre o futuro, o autor apresenta quatro hipóteses, que admite poderem comportar variantes matizadas, apresentadas como possíveis alternativas às actuais freguesias, que identificou do seguinte modo:

- Plena outorga da condição autárquica;

- Diferenciação do regime jurídico autárquico;

- Eliminação do carácter autárquico, mas permanecendo no sistema administrativo; e

- Desvinculação do sistema administrativo.

No primeiro caso, remete-se para uma maior autonomia da freguesia face ao município e para uma maior clarificação das atribuições e competências de cada um dos níveis autárquicos.

A segunda hipótese parte do reconhecimento de que a realidade das freguesias é muito diversa, para admitir a diversificação das suas responsabilidades consoante as suas "características geodemográficas e socioeconómicas" ou de conformidade com as dimensões paroquiais.

A terceira relega a freguesia para um organismo desconcentrado do município, que passaria a ser, na prática, um serviço municipal que teria ao seu dispor um conjunto de competências delegadas.

Como nota final, refira-se que a opção por uma abordagem histórica, desenvolvida pelo autor, mais do que preencher uma lacuna, contribui para dar uma visão mais completa deste nível autárquico e facilita a sua compreensão. No entanto, sem pretender retirar mérito ao trabalho, deve dizer-se que a última parte da obra abre o apetite para continuar a discussão iniciada.

A obra analisada constitui um importante contributo para o conhecimento da freguesia e dos seus antecedentes, interessando a todos os que se preocupam com a administração autárquica e a gestão do território. 